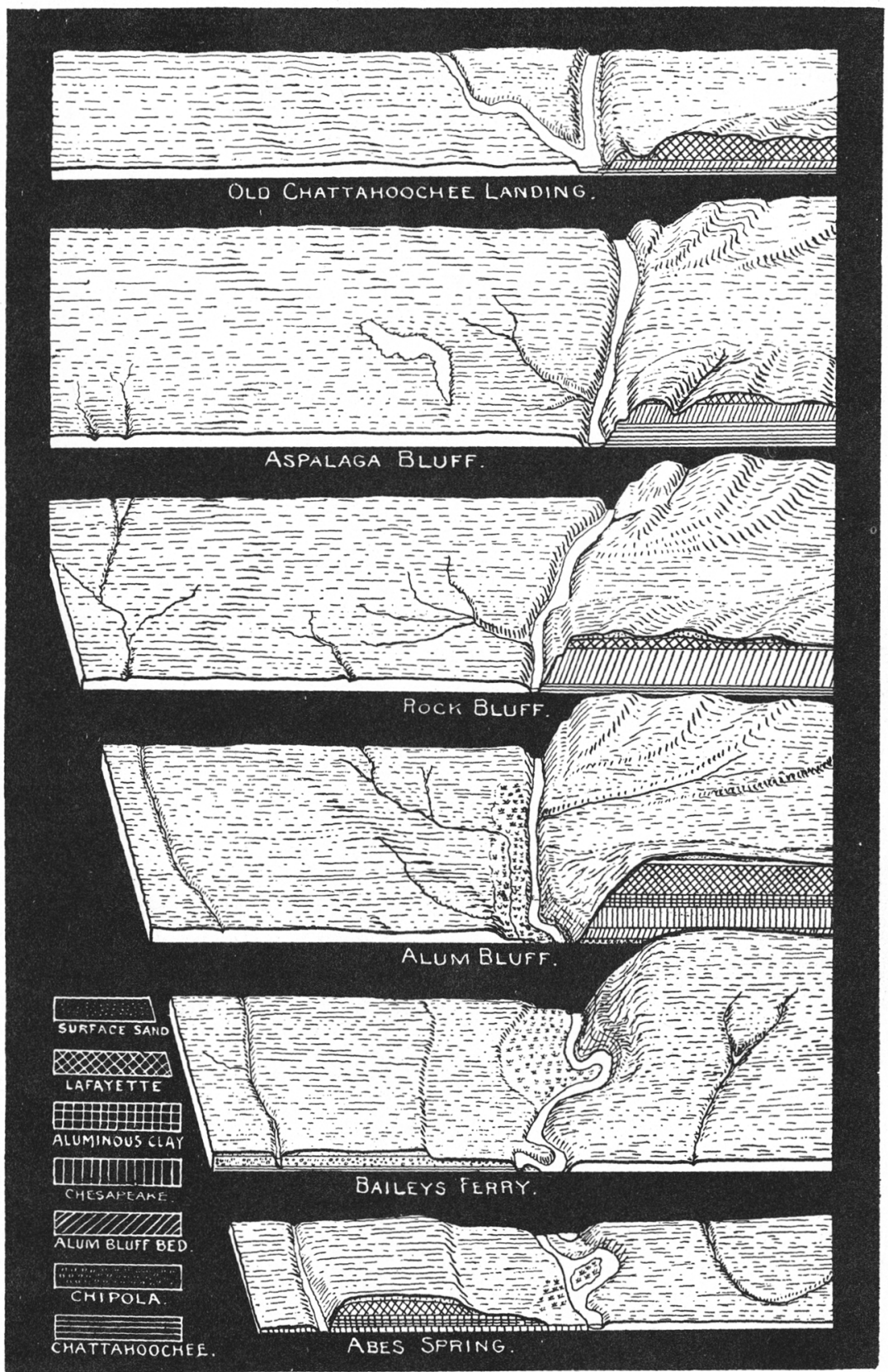

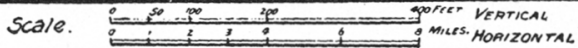

STEREOGRAPHIC MAP OF AREA ALONG APALACHICOLA RIVER FROM OLD CHATTAHOOCHEE LANDING TO BLOUNTSTOWN. 


\title{
CENOZOIC GEOLOGY ALONG THE APALACHICOLA RIVER*
}

\author{
BY WILLIAM H. DALL AND JOSEPH STANLEY-BROWN
}

(Read before the Society December 27, 1898)

\section{CONTENTS}

Page

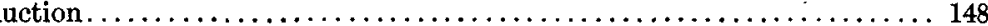

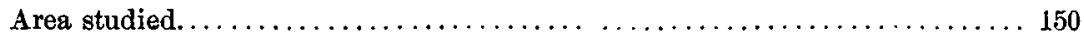

Localities in detail. . . . . . . . . . . . . . . . . . . . . . . . 151

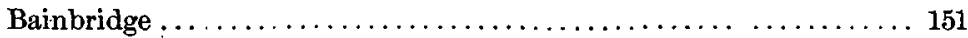

Blue Springs.................................... 151

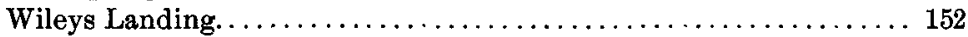

Old Chattahoochee Landing and Sections................. 152

Chattahoochee Landing $\ldots \ldots \ldots \ldots \ldots \ldots \ldots \ldots \ldots \ldots \ldots \ldots \ldots$

Aspalaga Bluff and Section $\ldots \ldots \ldots \ldots \ldots \ldots \ldots \ldots \ldots \ldots \ldots \ldots \ldots \ldots$

Ocheesee .......................................... 155

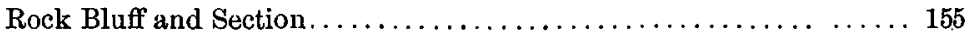

Alum Bluff and Section............................... 156

Jacksons Bluff and Section $\ldots \ldots \ldots \ldots \ldots \ldots \ldots \ldots \ldots \ldots \ldots, 158$

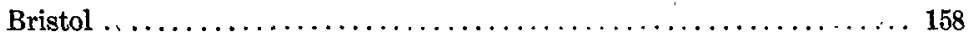

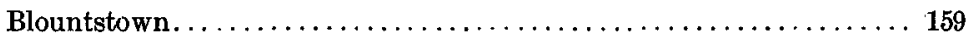

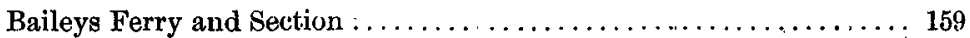

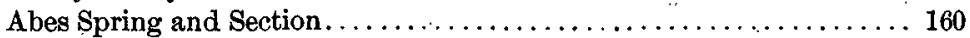

Darlings Slide and Section. . . . . . . . . . . . . . . . . . 160

Thomasville, Georgia ............................ 161

Conclusions as to the geologic Structure and Succession............... 162

Eocene........................................ 162

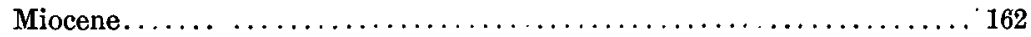

Chattahoochee Limestones. . . . . . . . . . . . . . . . . . . 162

Chipola Marl $\ldots \ldots \ldots \ldots \ldots \ldots, \ldots \ldots \ldots \ldots \ldots, \ldots \ldots \ldots \ldots \ldots 165$

Alum Bluff Beds............................... 165

Chesapeake or cold Water Miocene..................... 167

The Aluminous Clay . .............................. 168

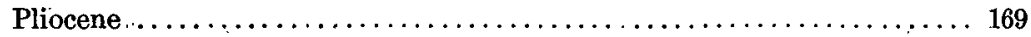

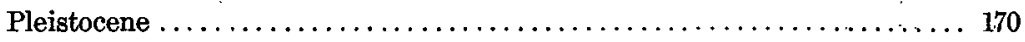

Correlaticin ........................................ 170

* Printed by permission of the Director of the United States Geological Survey.

XX-Butr. FEnt. Soc. AM., Vor. 5, 1893.

(147) 


\section{INTRODUCTION.}

The most complete series of Neozoic rocks in continuous succession which has yet been observed on the Gulf coast is that which is exhibited in the natural sections exposed in the bluffs of the Flint and Apalachicola rivers, in southwestern Georgia and western Florida. For this reason the series has been adopted in various publications * as a standard by which to correlate the different Neocene beds of this general region. The longest continuous series of beds in one section is exposed at Alum bluff, in township 8, range 1 north, section 24, Liberty county, Florida. Attention was first called to this series by Mr D. W. Langdon in $1889, \dagger$ from observations made two years earlier. At the suggestion of Mr T. H. Aldrich, who had identified Langdon's fossils, and, in coöperation with him, Mr Frank Burns, of the United States Geological Survey, was sent to Alum bluff in 1890, and a collection and section made by him were sent in. This section, in which the heights were determined with a pocket aneroid by Mr L. C. Johnson, who visited the bluff when $\mathrm{Mr}$ Burns was at work, was printed on page 113 of Bulletin 84, already referred to. In December, 1891, under the instructions of $\mathrm{Mr}$ George $\mathrm{H}$. Eldridge, Alum bluff was visited by a party, including Messrs L. C. Johnson and Edmund Jussen, from whom separate reports and sections are on file in the archives of the United States Geological Survey. Subsequently Dr J. W. Spencer with a party, and Professor Raphael Pumpelly, assisted by Mr A. F. Foerste, examined this locality. A valuable paper by the latter gentleman has recently appeared $\ddagger$ and Professor Pumpelly has published§ additional data establishing an unconformity at the base of the Neocene in this series.

In the above enumeration only those visitors through whom information about Alum bluff has reached the writers of this paper are referred to, though several other observers are believed to have visited the locality.

The importance of the Apalachicola section for southern geology is manifest, and the fact that there were serious discrepancies between the various accounts of it hitherto accessible, not only concerning the succession of the beds and their exact nature, but even in regard to so simple a matter as the height of the bluff, decided the writers of this paper, with the approval of the Director of the United States Geological Survey, to reëxamine the subject on the spot. Previous observations

* Bulletin 84 (Neocene), U. S. Geological Survey, 1891. Transactions Wagner Free Inst. Sci. vol. 3, 1890-92, etc.

t Am. Jour. Sci., third series, yol. 38, p. 324.

+ Studies on the Chipola Miocene, Am. Jour. Sci., vol. 46, Octoher, 1893, pp. 244-54.

\& Am. Jour. Sci., vol. 46, December, 1893, pp. 445-447. 
placed the total thickness of the strata above water at Alum bluff, at low stages of the river, at 63 feet, others at 125 feet. The earlier observers regarded the clay above the Chesapeake marl as lignitic, which led to its correlation with other lignitic beds to which attention has been

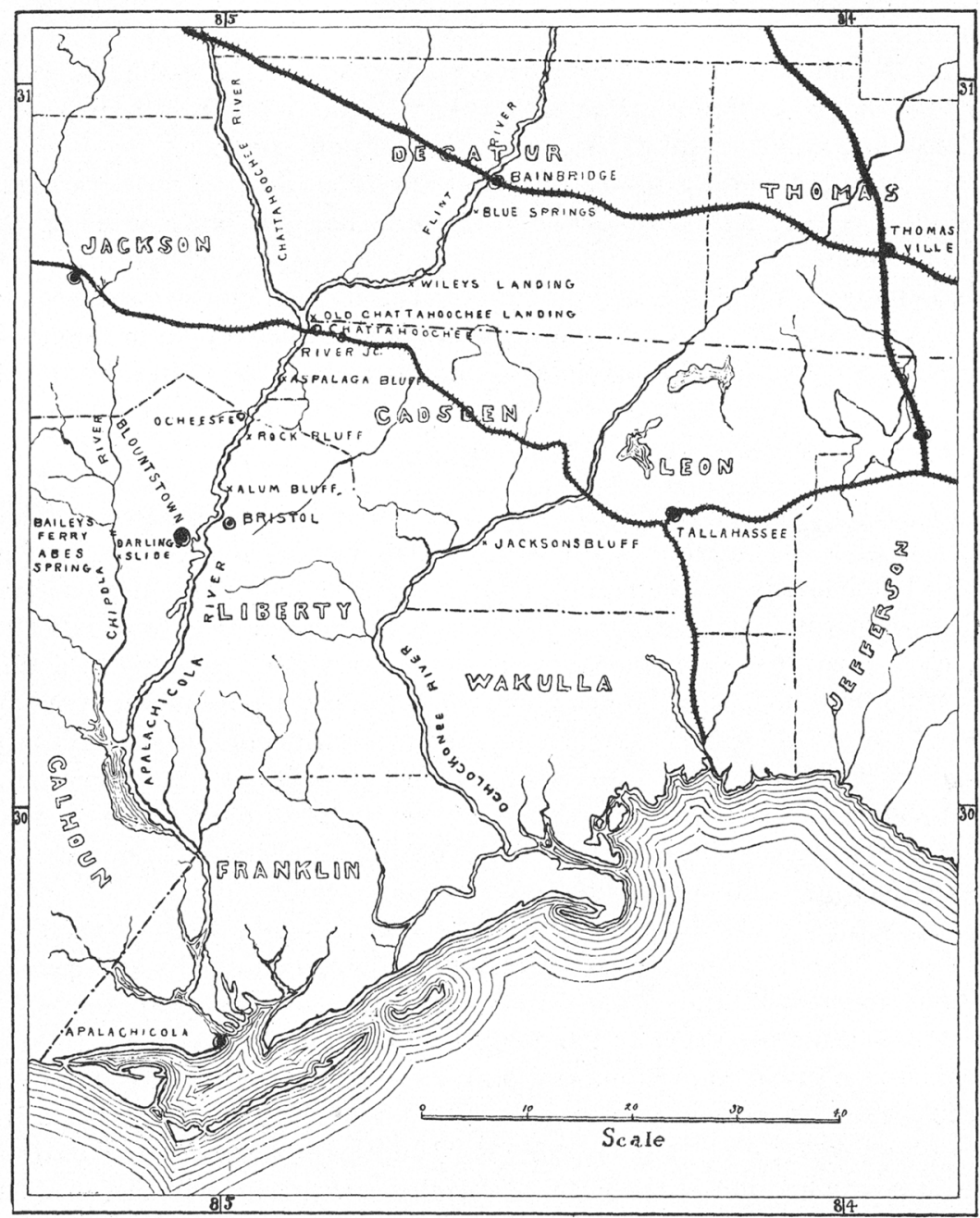

Figure 1.-Map of Portions of southwestern Georgia and central western Florida.

directed. Mr Foerste, however, pointed out that the principal source of the phytogene remains of this locality is in the Alum bluff sands. The pecteniferous marl of Rock bluff had been referred to the newer or Chesapeake Miocene, and its most prominent fossil wrongly identified. 
Its correlation with the proper horizon in the Alum bluff section was necessary to a right understanding of the geology over a considerable area. Finally, the sections hitherto made had not been precisely located or exactly measured, part of the discrepancies alluded to doubtless arising from examination of the beds at different instead of identical points.

The season chosen for our work was that of the river's lowest stage, which, owing to drouth, was, as we were assured by old lumbermen, within two or three feet of the lowest water known to them.

It should be noted in passing that the identification of the various bluffs and landings is not easy unless one has an experienced riverman as guide, and in view of the fact that the maps are often incorrect, that changes in the location of landings and even of towns are made with great facility, and that places formerly occupied are now deserted, it is not surprising that travelers are misled as to local nomenclature.

\section{AREA STUdied.}

In making the investigations upon which this paper is based, the following plan* was adopted: We proceeded by rail via Atlanta, Macon and Thomasville to Bainbridge, the head of navigation on the Flint river, Decatur county, Georgia. There we procured two rowboats and floated down the Flint river to its junction with the Apalachicola at the Florida boundary, and thence down the latter river to Blountstown, Calhoun county, Florida, below which the low swamps of the coastal plain begin. This plan made it possible to camp at localities where investigations were to be made, and also to make such excursions inland from the river as were deemed desirable. The points visited are enumerated in the detailed statements presented later.

Descending the Flint river, the rocks, which belong to the Vicksburg series of the Eocene, characteristically distinguished by the presence of Orbitoides mantelli and Pecten poulsoni and perplanus, appear above the water at intervals only, and are separated by low areas where the red beds and alluvial mud alone rise above the river. The higher land exhibits the character of gentle, anticlinal folds through which the river cuts its way, forming bluffs which afford in most cases very good natural sections. The land at the river is usually somewhat lower than can be found a few miles away on either side, even at the bluffs, but owing to the thick mantle of gravel and rather dense undergrowth these more distant hills afford no convenient exposures. The number of parallel

\footnotetext{
* For most valuable suggestions and assistance we are especially indebted to Professor $\mathrm{R}$. Pumpelly, Major T. B. Brooks, Profeswor E. A. Smith, State Geologist of Alabama; Mr Dubois and Mr R. A. Lytle of Bainbridge, Georgia; Mr Frank Burns and Mr Wood of Blountstown, Florida.
} 
folds between Wileys landing and the edge of the coast swamps appeared to be not more than five or six, and as nearly as could be judged the folds are successively higher, culminating at Alum bluff, which reaches 161 feet above low water by careful measurement. Part of this difference in height may be due to the slope of the channel of the river seaward, but it is probable that a moderate increase in absolute height does take place. The bluffs along the river furnished convenient sites for Indian villages, and shards of pottery, arrow-heads, flint chips, excavations and other evidences of occupation are readily found.

\section{Localities in Detail.}

Bainbridge.-Professor Pumpelly * has recently described the remnants of the Chattahoochee and Chipola beds which are found in various places about Bainbridge superposed upon the Vicksburg Eocene rocks, from which they are separated by an unconformity. These Miocene remnants represent what is left after solution by water and carbon dioxide has removed the greater portion, estimated by Professor Pumpelly as having reached in some places a thickness of 200 feet. Only the silicified fragments of rock and molds or siliceous pseudomorphs of the fossils now remain. Over and partly including them is an extensive series of reddish clays, sands and gravels, which of late have been referred to the Lafayette formation of Hilgard and McGee, covered by yellowish gray incoherent superficial sands (Columbian?) and a thin coating of humus. Elsewhere in this paper (page 169) reasons are given for the belief advanced by Professor Pumpelly that the red beds are of a composite nature, and to a greater or less extent, depending upon locality, are made up of residual material in its original location or but slightly transported by aqueous action. The remnants of small quartz dikes broken up into fragments but still retaining a nearly vertical position and of thin broken siliceous sheets hardly moved from their horizontality in the gravels seem to establish this fact beyond controversy. Elsewhere and espeally on the upper surface of the red beds, worn and rounded material testifies to a rearrangement and more or less transportation of part of the original material. As further seaward similar material covers beds later than the newer Miocene, it is probable that this part of the red beds of this region is of not earlier than Pliocene age.

Blue Springs.-At Blue springs, Flint river, Georgia, about four miles below Bainbridge, limestones with Vicksburg fossils are the prevalent rock, but above them Professor Pumpelly obtained fragments of highly silicified rock containing casts of Orthaulax and Amauropsis burnsii, be-

* Am. Jour. Sci., vol. 46, December, 1893, pp. 445-447. 
longing to the Chattahoochee formation. This locality was not visited by us.

Wileys Landing.-At a place on the left bank of the Flint river a few miles above the Florida boundary line, known as Wileys landing, Professor Pumpelly states that the contact between the Vicksburg and undisturbed Chattahoochee Miocene may be observed. Unfortunately this interesting locality was missed, owing to a severe storm of wind and rain and the fact that our pilot was not acquainted with the place by that name.

Old Chattahoochee Landing and Sections.-The first stop of importance was made at old Chattahoochee landing, which is on the Apalachicola river just below the mouth of the Flint and in township 3 north, range 6 west, section 5 . This was formerly a landing for river steamers, but is now superseded by the landing at the railroad bridge about a mile below. A single house stands on a mound near the river which formerly afforded a village site to the Creek Indians. From the old landing place two roads diverge, one toward the northeast, the other to the southeast. The latter is the older and no longer passable for vehicles, being gullied out by water. Both ascend the bluffs at a short distance from the river and come together on the hills a short distance beyond. A roughly levelled section was taken on each of these roads.

\section{Sections at Old Chattahoochee Landing.}

1. Reddish sand and gravel, with streaks of clay............ 20 to 40 feet.

2. Grayish yellow friable marl, with harder layers............ 20 "

3. Greenish clayey marl, very adhesive................ $2 \frac{1}{2}$ "

4. Chattahoochee limestone, with fossil casts............... 4 "

5. Talus to water's edge, about..........................

Total thickness .................................. $\overline{49 \frac{1}{2} \text { to } 699^{\frac{1}{2}}}$

This section was taken on the road running northeast from the landing.

1. Reddish sands, gravel and clays .................. 15 to 20 feet.

2. Grayish yellow marl, friable $\ldots \ldots \ldots \ldots \ldots \ldots \ldots \ldots \ldots \ldots \ldots .20$ "

3. Greenish clayey marl, sticky. . . . . . . .

4 . Talus to water's edge, about....................... 3 "

Total thickness........................ $30 . \overline{30 \frac{1}{2} \text { to } 45 \frac{1}{2}}$ "

Section number 2 was taken on the road which runs about southeast from the landing. The exposures are mostly in the gullies.

The fossil-bearing bed is number 4 , and contains, among other fossils, echinoids, Pecten (Chipola sp.), Arca (like transversa), large solitary coral, Venus penita, Lima (like scabra), Hemicardium, Ostrea, Loripes, 
Scala, Plicatula, Divaricella, Pyrazisinus, Phorus, all as poor casts; fishbones, and ribs of some mammal resembling those of the manatee. No orbitolites were seen.

Chattahoochee Landing.-At New Chattahoochee landing. where the railroad-bridge crosses the river, the bank is chiefly alluvial mud, with fragments of rock from the Chattahoochee limestone. The railway-trestle continues eastward from the bridge, across land submerged at high water, about a mile to a point known as River Junction or Chattahoochee station of the Savannah, Florida and Western railroad. Here two roads divide; one, the above mentioned, extends into Georgia, the other eastward in northern Florida. Half a mile from the station, on the first mentioned road, there are several cuttings, where, under the usual red beds, 5 to 10 feet in thickness, the Chattahoochee limestone is exposed in place. Here it is a residual rock, clayey white and yellowish, with conchoidal exfoliation. The fossils have mostly been removed by solution and their traces are very indistinct, but nearer the station the same rocks are visible in the bottom of an excavation made to obtain material for an embankment. Here distinct imprints of fossils occur, and even poorly preserved shells in some places. In the first locality the Chattahoochee limestone rises some 5 feet above the track, covered with yellow and ferruginous clayey streaked sand, more clayey at the top, over which is about 3 feet of gray superficial sand and humus. At the second locality the rocks are 8 to 10 feet below the track, and here Burns in 1890 collected Pyrazisinus cornutus, Cerithium hillsboroensis, Potamides transecta, Conus planiceps, Natica amphora, Lucina hillsboroensis, Cardita serricosta, Venus staminea, $V$. cancellata, $V$. penita, Cytherea nuciformis, Cyrena vesica and Orbitolites floridanus. There were among the undetermined species Tagelus, Solen, an echinoid and some obscure corals.

Aspalaga Bluff and Section.-About five miles below the bridge, on the left bank, the first prominent bluff is that at Aspalaga landing. This bluff, which is in township 3 north, range 7 west, section 35 , extends half a mile along the river, rising abruptly about $7 \tilde{o}$ feet, and further back attaining a height of perhaps nearly as much more. The upper part of the bluff is sloping and much obscured by talus and vegetation; the lower part is nearly vertical, offering the thickest single exposure of the Chattahoochee limestone to be found anywhere on the river. The beach comprises a narrow strip of talus, but, from appearances, at least 10 feet of limestone exists below that part which is distinctly exposed. The limestone is composed of ill defined, nearly horizontal beds, alternating harder and more friable, partly free from organic remains and partly containing typical Chattahoochee fossils rather poorly preserved. A small piece of this limestone, with Orbitolites and other remains, was 
found by Dr. Foerste at a height estimated at 130 feet above the water, but this was doubtless transported in some way from below. At the highest point of the bluff; where this limestone showed the thickest exposure, about 40 feet were visible and ten feet more probably concealed by talus and water. Above it lies about 20 feet of bluish green marl, conformable to the limestone, and much of which is unfossiliferous. In places, however, there are layers of small oyster-shells and a Pecten which has somewhat the appearance of a young Pecten madisonius, and has been mistaken for that species. It is, however, a Chipola species, and may prove new. This marl was observed by Mr Jussen, whose manuscript section we confirmed on the spot; it is what Mr. Johnson has called * the "Aspalaga clays," assigning it a thickness of 60 feet; but his section is evidently too much generalized, and the bed did not exceed 20 feet in thickness at any point where we were able to observe it. Mr Johnson's heights were measured with a pocket aneroid and seem excessive; that method of measurement, without careful correction and comparison, being but little to be relied upon.

Above the marl at the edge of the bluff, omitting talus, there appeared to be about 5 feet of reddish clay and gravel, but further back this thickness is very greatly surpassed, and may reach 40 or 50 feet. On account of the manner in which the upper part of the hill is weathered and overgrown, a large amount of time and labor would have been required to expose and verify a complete section. We therefore confined our work to the verification of the actual section facing the river.

It is to be mentioned that in Mr Langdon's paper, previously alluded to, he gives a section at a point which he calls "Ocheesee," which subsequent observers have not identified, but which Mr Johnson suggests may be the same as Aspalaga bluff, which is not mentioned by Mr Langdon. The discrepancy in height and stratigraphy forbids us to accept this identification; and, indeed, we did not observe any place where the strata clearly recalled those mentioned in Langdon's section. At the present Ocheesee landing the bank is wholly of alluvial material, and is on the opposite side of the river, so Mr Langdon's section could not have been made there.

\section{Section at Aspalaga Bluff.}

Superficial sand, mostly absent at river..................... 0 feet.

Reddish sands and gravel, with streaks of clay................

Bluish-green clayey marl, with Ostrea and Pecten...............

Chattahoochee limestone, hard and soft layers................. 40 "

Talus to water (probably Chattahoochee) $\ldots \ldots \ldots \ldots \ldots \ldots \ldots \ldots \ldots \ldots \ldots \ldots \ldots \ldots$

Total thickness above water...................... $\overline{75}$ “ 
The section here was taken at the highest part of the bluff rising from the river and about midway between the two ends.

There is below low-water level probably 10 or 12 feet more of the Chattahoochee limestone, worn vertically or nearly so by the action of the current.

Ocheesee.-About three miles below Aspalaga, on the opposite side of the river (right bank), is Ocheesee landing, marked by several buildings, one of which was once a fine large frame house built on piers. The lower floor was apparently nearly twenty feet above the level of the water at the time of our visit, yet we were told that skiffs had been paddled in at the front door and out the back door, through the central hall, during one of the freshets. As the land is very level and not high within sight of the river, it would seem as if an incalculable amount of water would be required to raise the level to the height mentioned.

Rock Bluff and Section.-Below Ocheesee is a long stretch of river nearly straight, known as "Seven-mile reach." On the left bank, about two miles below Ocheesee, in township 2 north, range 7 west, section 19 , rises Rock bluff, the face of the third principal anticline cut by the river below the Florida line. It creates a slight bend and offers an excellent, clean section. The settlement named Rock Bluff is four or five miles inland from the river-bank, and should not be confounded with the landing.

The lower part of the bluff formed by the Chattahoochee limestone is vertical, rising twelve feet above the water, and presumably nearly as much below it, at low stages of the river. Above this is a mass of marl varying from bluish green to gray in color, weathering white, more arenaceous below and more marly above, replete with oyster-shells, a fine, large Anomia, a pecten, like young madisonius (but, as observed by Foerste, only four-sevenths the size of that species; it is really a Chipola species); a Turritella and many Balani. This assemblage of species indicates a shallow water oyster-reef fauna, unquestionably belonging to the old Miocene and forming the shoal-water equivalent of the Chipola and Alum bluff beds, especially the latter. Above this marl lie the red Lafayette clays and gravels-in this case worked-over materials-variable in thickness, owing to denudation, but apparently averaging about fifteen feet, and covered with a thin layer of superficial soil and sand. This section was carefully measured with a steel tapeline, due allowance being made for the inclination of the tape from the vertical. It shows the finest and thickest section of the greenish marl exposed anywhere on the river. The contact of the marl with the Chattahoochee limestone is distinct and without apparent unconformity or transition beds of any kind. 
The section was measured on the highest part of the bluff, which is the first approached as the turn of the river is made in descending.

Section at Rock Bluff.

1. Superficial sands, thin and variable, say................. 3 feet.

2. Reddish clayey sand and gravel, about........ "

3. Greenish white compact marl, with fossils.................

4. Chattahoochee limestone, to water.................. 12 "

Total thickness above water.....................

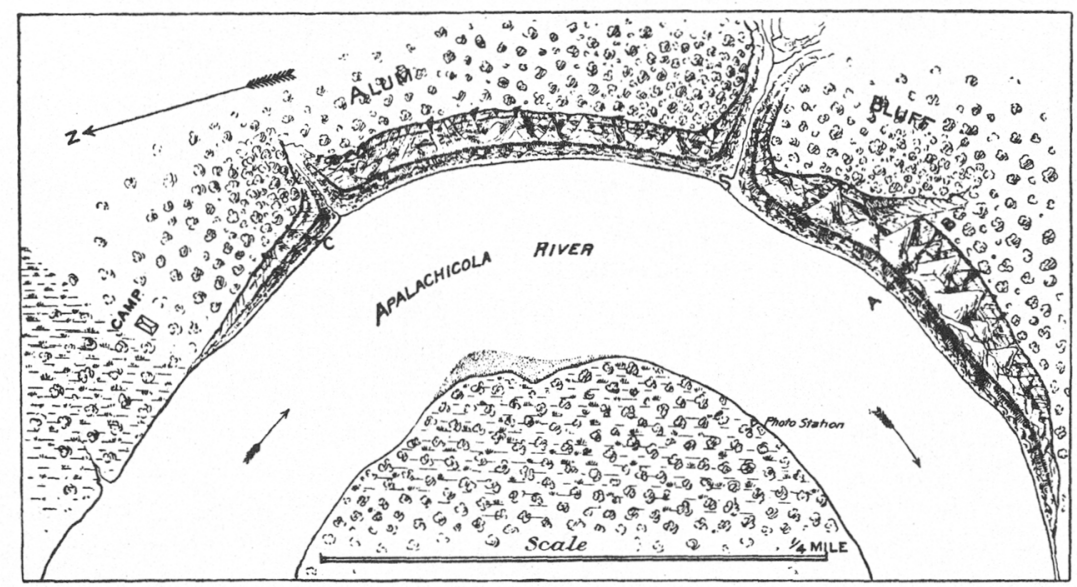

Figure 2.-Sketch-map of Alum Bluff.

Alum Bluff and Section.-Five miles below Rock bluff the reach terminates by a semicircular bend convex toward the west and followed by another convex to the east. The latter is bordered by a cliff called Alum bluff, which is in township 1 north, range 8 west, section 24 . It is hollowed out of the fourth anticlinal fold south of the Florida line, extends for about half a mile on the left bank of the river, roughly northwest and southeast in trend, lower toward the north, highest in its southeastern third, and cut transversely somewhat southeast of its center by a small deep valley of erosion. The bluff in a general way may be divided vertically into two parts, the lower, forming a bench about midway, crowned by a layer of acid clay from which water issues, leaving a saline efflorescence on the face of the bluff, from which the latter derives its name. Standing at the foot of the bluff, nothing can be seen above this clay, the more arenaceous strata above having weathered back at a lower angle, though still nearly vertical above. Upstream above the bluff the river bank is a swamp, mostly of alluvial clay; the right bank 
is little else as far as the eye can reach. Camp was made at the north end of the bluff. A section was most carefully made at the highest exposure, with steel tape, portable transit and stadia, a small baseline and triangulation being measured for that purpose; the weathered surface of the strata shaved clean with a spade and photographed; some of the fossil plants, being too frail to transport, were photographed in situ; a general panorama of the bluff was photographed from the opposite bank of the river, and some fossils with a series of rocks collected for analysis and study. The large collection obtained here in 1890 by Mr Frank Burns rendered it unnecessary to spend much time in searching for fossils.

The section was taken at the part of the bluff indicated by $A-B$ on the sketch-map.

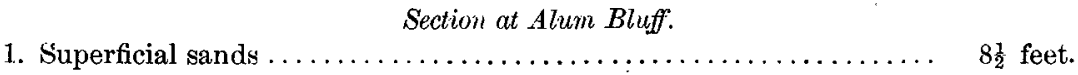

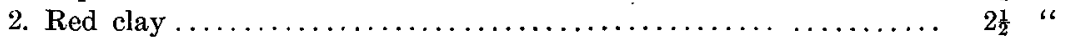

3. Reddish and yellowish streaked sands............

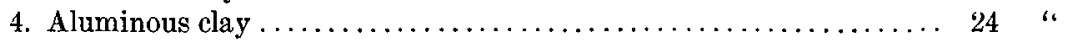

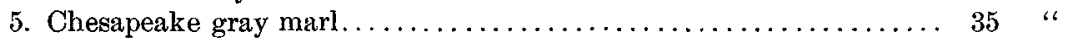

6. Alum bluff sands with streaks of clay.. $\ldots \ldots \ldots \ldots \ldots \ldots \ldots \ldots 21 \frac{1}{2}$ " "

7. Hard Chipola marl to water (variable) .................. 31 "

Total thickness above water................... $160_{4}^{3}$ “ “

The composition in detail of these several beds is as follows:

Number 1.-Pale yellowish gray incoherent sand.

Number 2.-Hard reddish clay weathering with vertical face.

Number 3.- Streaky yellowish and reddish sands with small littleworn gravel, of siliceous character, mixed with it. Near the lower third a few obscure impressions, possibly representing fossils, were observed by Mr Stanley-Brown. The lower 3 feet of the sands is more or less loamy from admixture with underlying clay. They are distinctly stratified in conformity with the other beds of the bluff.

Number 4.-Tough gray aluminous clay weathering nearly vertical with a very few fragments of vegetable matter in it. and some obscure indications of gastropod and bivalve fossils, the shells entirely dissolved and represented chiefly by color-marks in the clay. The appellation of. "lignitic," heretofore applied to this clay on the authority of Mr Johnson, cannot be regarded as justified, as the amount of phytogene material is trifling. The fossils may have been marine or fresh water. No satisfactory evidence is afforded by their faint traces, as observed by us.

Number 5.-Bluish gray tough clayey marl replete with characteristic Chesapeake fossils, especially Mactra congesta. The upper six inches is discolored by iron oxide, derived from the water oozing from the bed above, which has also dissolved the shells, leaving only cavities. Toward 
the north, at a point ( $C$ of figure 2) near the camp, the Chesapeake is thinned to 5 or 6 feet in thickness.

Numbers 6 and 7.- The Chipola marl is compact and of a darkreddish color from hydrated peroxide of iron contained in it. The fossils which are abundant are rather soft. Orthaulax is the most common shell; there are no traces of Orbitolites. The matrix is chiefly sand mixed with clay. At least 6 or 8 feet of the Chipola is below the water; it rises at the low est stage of the river from 3 to 11 feet above the water's edge, weathering almost like a rock. There is no well defined line of separation between the marl and the Alum Bluff sands (number 6) above it, but the change takes place in a space of 5 feet, the lower portion of the sands containing more or less of the Chipola fauna. Above this they are mottled bright ferruginous and yellow, and exhibit distinct marks of cross bedding. They contain sheets-laminæ or lenticular streaks of clay--which show abundant leaf remains resembling willows and other water-loving plants, while the sands in the lower part of the bed contain large leaves and stalks of palmetto or other palm-like vegetation, the thicker parts of which are reduced to the condition of lignite. These are too friable to remove without previous hardening applied in situ. The upper part of these sands did not show any fossil remains at the points where we examined them.

Toward the north ( $C$ of figure 2), where the bluff is much lower and the Chesapeake thinned out to 5 or 6 feet in thickness, the sands below it are unfossiliferous and modified. The upper part is more exclusively sandy, and, lower down, the bed assumes the clayey compact greenish color of the oyster marl at Rock bluff, a few miles above, but here the green marl contained no fossils.

Jacksons Bluff and Section.-In this connection, as confirming the identity of age and position of the greenish marl, a section taken by $\mathrm{Mr} \mathrm{E}$. Jussen, of the United States Geological Survey, may be cited. This section was made at Jacksons bluff, situated in township 1 sonth, range 4 west, section 17, on the Ochlockonee river, Florida, being about twentyone miles east and six miles south of Alum bluff.

Section at Jacksons Bluff:

Superficial sands................................... ó feet.

Chesapeake bluish marl, with Mactra congesta................ 8 "

Gray marly bed, with oysters and Pecten...................

Total thickness... . ............................ $\overline{35}$ "

Bristol-From Alum bluff we descended the river to Bristol and Blountstown, the former a landing on the left bank in township 1 north, range 8 west, section 36 , with the village of the same name about a mile inland from the river bank. At the linding alluvium and clayey beds 
alone rise above the water. Between the landing and Blountstown, three miles westward, there is a shoal in the river, popularly reported to be rocky, but too much covered to be examined without a dredge.

Blountstown.-Blountstown, named from the village of an ancient chief called Blount by the whites, is in township 1 south, range 8 west, section 3 , on the right bank of the river. A short distance above the landing is a large mound, formerly occupied by the Indians as a village site. The bank at this place, which contains several dwellings, a store, the county courthouse and a primitive jail, is chiefly composed of clayey alluvium, and is partly overflowed at high water in the river. High water in 1886 left a mark on the houses 4 feet above the ground. About eight miles westward is the Chipola river, flowing in a southerly direction, on the banks of which are several outcrops of the Chesapeake and Chipola beds, in which the fossils are in a better state of preservation than at Alum bluff, and the Chipola marl may be observed resting conformably upon the Chattahoochee limestone. The water being extremely low, within a foot or two of its lowest observed stage, as we were informed, the opportunity was extremely favorable for examining these outcrops. Obtaining a conveyance, we drove from Blountstown over to the Chipola river to inspect them.

Baileys Ferry and Section.-The principal localities of interest on the Chipola river are those near a point called Baileys ferry, where a bridge has replaced a former ferry, but no village exists, the farms being scattered. This ferry is not on any map, but is believed to be situated in township 1 north, range 9 west, section 32 . Just above the bridge, on the right bank, the ferruginous Chipola marl may be seen rising two or three feet above the water's edge, the bank at the lowest stage of the water being six or eight feet high. This is said by residents of the vicinity to be the most northerly point on Chipola river where the yellow marl is visible in the bank. A few miles west, on a branch known as Ten-mile creek, the Chipola marl rises much higher and reaches so near the surface at Stevens spring that the plow throws out hundreds of fine fossils in turning a furrow. We were not able to visit Mr Stevens' place, but half a mile below the bridge, on the right bank, is a farm belonging to Mr John McClellan, on which a fairly good section can be studied along the river bank, and here the following section was made:

Section at McClellans Marl-bed, Baileys Ferry.

Superficial sands, 1 to 3 feet, say $\ldots \ldots \ldots \ldots \ldots \ldots \ldots \ldots \ldots \ldots \ldots \ldots$ feet.

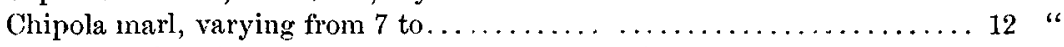

Chattahoochee limestone at water's edge, extending below not less than. 6 "

Total thickness.............................. 
The marl is extremely rich in fossils; Mr Burns obtained over 400 species in a few days' work at this locality. It contains a certain proportion of clay and much calcareous matter, and is of a pale yellowish color. It shows no Orbitolites, but Orthculax, Cypræa, Ancilla, Fusus, Conus, Cerithium, etc, show characteristic fossils beautifully preserved and of good size. It is probable that the beds which lie above the Chipola have been denuded in this vicinity. The importance of the section lies in the presence of the typical Chipola marl conformably upon the Chattahoochee limestones, which last at Alum bluff are below the surface of the river, if present. The left bank here seems to be alluvial.

Abes Spring and Section.-Three or four miles south from Baileys ferry, on the left bank, is a settlement of scattered houses which from a spring which issues near the river has received the name of Abes spring. It is situated on the south line of township 1 south, range 9 west, section 17. The right bank of the stream here seems to be low and alluvial, rather densely wooded.

The section here was measured with a steel tapeline on the left bank of the Chipola river, Calhoun county, Florida, at the bluff about 200 feet north of the spring, which here flows from a wooden pipe.

Section at Abes Spring.

1. Superficial sands, about............................ 4 feet.

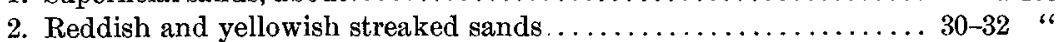

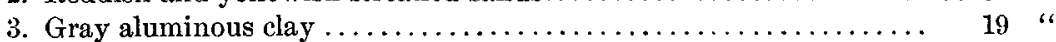

4. Chesapeake gray marl to water (variable) $\ldots \ldots \ldots \ldots \ldots \ldots \ldots \ldots, 7$ "

Total thickness above water.................... 62 "

In detail these strata have the following composition:

Number 1.-Pale yellowish gray incoherent sand, such as might be deposited by a river during seasons of high water-less like beach-sand than the analogous material at Alum bluff.

Number 2.-Of the same character as number 3 of Alum bluff. The material is generally a little coarser and the gravels a little larger, and there is also greater heterogeneity in structure.

Number 3.-Same as number 4 (aluminous clay) of Alum bluff.

Number 4.-Chesapeake, just as at Alum bluff.

Darlings Slide and Section.-On the Chipola river, a mile or more north of Abes spring, is a "slide" where timber is cast into the river for the construction of rafts, which are floated down the river to the mills at Apalachicola, on the Gulf. This place is locally known as Darlings slide, and is a very steep natural bank, affording an excellent section, though 
somewhat obscured by weathering and the friction of the enormous logs which are rolled over it. It is on the left bank, and the bank opposite is low and apparently of alluvium.

\section{Section at Darlings Slide.}

1. Superficial sands................................. 3 feet.

2. Reddish and yellowish streaked sands................. 18-20

3. Gray aluminous clay (presence or thickness uncertain) $\ldots \ldots \ldots \ldots\} 27$ "

4. Chesapeake marl to water (variable) ...................

Total thickness above water.................. 50 "

The composition of the several beds is as follows:

Number 1.--.Pale yellowish gray incoherent sand, such as might be deposited by a river during floods-less like beach-sand than the analogous material at Alum bluff.

Number 2.- Of the same character as number 3 of Alum bluff. The material is generally coarser and the gravels a little larger. There is also greater heterogeneity in structure.

Number 3.-The conditions were unfavorable for determining the presence or thickness of the gray aluminous clay, but from the fact that it is well exposed with sharp contacts at Abes spring, but a short distance south, and, together with the Chesapeake, makes up 27 feet of thickness, it is reasonable to suppose that it forms part of the 27 feet assigned to 3 and 4 .

Number 4.-Chesapeake marl, in every respect the same as that formation found at Alum bluff.

It is notable that nothing below the Chesapeake is visible, although it has been stated that the Chipola beds exist under the gray marl. This can only be an assumption, since, with the water, as we were informed, within a foot of its lowest stage, nothing of the sort was visible, nor does the stream show any material such as would be washed out of the older Miocene beds, if present. The principal fossil here, as at Alum biuff, is Mactra congesta, Conrad, with which are associated Venus mercenaria, L., and Turritella variabilis, Conrad. The beds above the Chesapeake appear to be destitute of fossils.

Below Abes spring the banks of the Chipola become lower and swampy and the river enters the so-called Dead or Chipola lakes, noted-as a fishing ground, through which it connects with the Apalachicola by a cutoff. Seaward from this extend the great swamps of the coastal plain.

Thomasville, Georgia.-On the line of the Savannah, Florida and Western railroad leading toward Albany, Georgia, and from half a mile to a mile from the center of the town, there are several cuts which give good exposures of the reddish gravels which cover most of this region and have been referred to the Lafayette formation. These beds contain much 
clay, together with small, slightly rounded fragments of quartzose material, and near their upper surface numerous small, dark colored, very round gravel stones, quite uniform in size, stained with iron and looking like peas or buckshot. The lower part of the clays shows evidences of stratification, thin sheets of harder material still remaining, broken up, apparently in situ, but formerly continuous. Occasionally a small dike of quartzose material may be seen standing in the gravel in its original position.

\section{Conclusions as to the Geologic Structure and Succession.}

The different portions of the generalized section for the Apalachicola region above the Vicksburg limestone which have actually been observed are shown on the accompanying diagrams, together with a column representing the whole series. The relative thickness of the beds is accurately represented in the diagrams, except that in the ideal column the thicker beds are somewhat diminished in order to bring it within the limits of the page. It will be seen on examination that, while the series is not complete in any single section, taken collectively there is no gap outstanding between the beds and, humanly speaking, no room for misapprehension as to their position and age. Being variable in thickness at different points, an average thickness has been assumed for the ideal section, except in the case of the Chattahoochee limestone, which has been put at 50 feet, and the Vicksburg at a nominal thickness, owing to exigencies of space.

To avoid possible confusion the symbols used in the sections are also employed in the sterographic map accompanying the paper. This map, while approximately accurate in its geographic boundaries, is necessarily highly generalized topographically and is merely a conventional presentation of the relation of the several localities and formations.

\section{EOCENE}

Beginning at the base of the column, Professor Pumpelly has shown that the Chattahoochee series rests on an erosion surface of the Vicksburg or Orbitoidal limestone which forms the culmination of the Eocene rocks. We have confirmed this by an examination of the fossils submitted by Professor Pumpelly, who also considers that the Chattahoochee and Chipola beds in southwestern Georgia attained a thickness of some 200 feet, which has been reduced by solution and settlement to a very small fraction of that amount.

\section{MTOCENE.}

Chattahoochee Limestones.-At Aspalaga the Chattahoochee limestones are in evidence to the amount of 50 feet before disappearing below the 
water and talus to an unknown depth. They consist of clayey limestones, some layers of which are harder than others, occasionally thor-
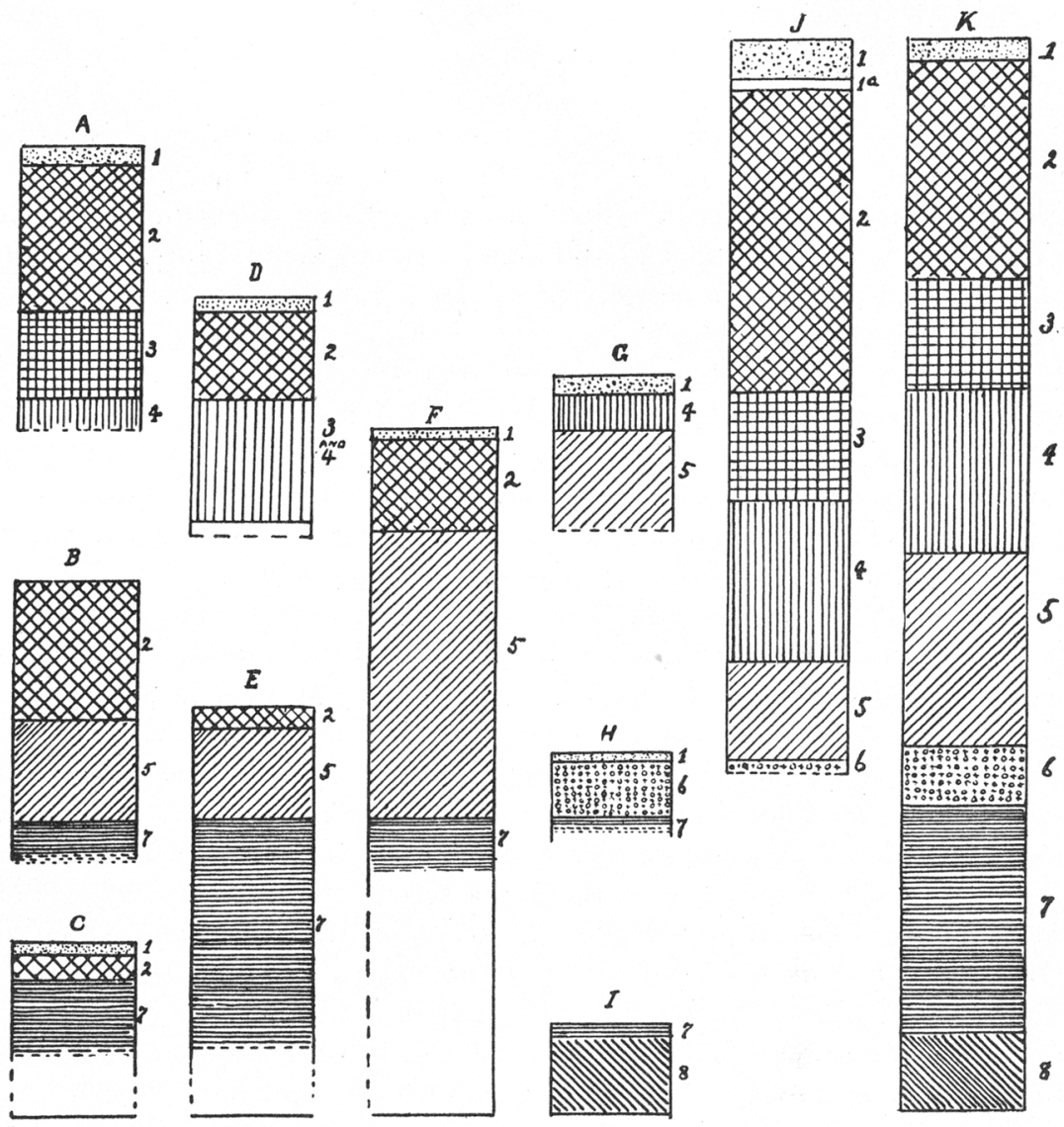

Figure 3.-Generalized Section and Sections exposed on the Chipola, Apalachicola and Ochlockonee Rivers, Florida.

A. Section at Abes spring, Chipola river, Florida.

B. " " Old Chattahoochee landing.

C. " " "River junction, Savannah, Florida and Western railroad.

D. " " "Darlings slide, Chipola river.

E. “ " Aspalaga bluff, A palachicola river.

F. " " Rock bluff, A palachicola river.

G. " "Jacksons bluff, Ochlockonee river.

H. “ “McClellans marl-bed, Baileys ferry, Chipola river.

I. " " "Blue springs, Flint river, Georgia.

J. “ " "Alum bluff, Apalachicola river, Florida.

K. " "Ideal section showing relative thickness and succession of the beds.

The definitions assigned the figures are as follows: 1, superficial sands; 2, Lafayette beds; 3, aluminous clay (Pascagoula ?); 4, Chesapeake marl; 5, Alum bluff beds ; 6, Chipola marl ; 7, Chattahoochee series; 8, Vicksburg Eocene limestones.

The figures are the same for all the sections. In sections A to $J$ the relative thickness of the beds is represented on the natural scale.

XXII-Bull, Geol. Soc. Am., Vor. 5, 1893. 
oughly silicified, usually of a pale yellow color, but in the more siliceous portions white or gray or, when partially oxidized, varying in shades of ferruginous brown. The remnants left by solutionary processes are almost always reddened by oxidation. The beds which in other parts of Georgia and Florida may be correlated with the Chattahoochee series are as follows: The Hawthorne beds of central Florida and the thin layer containing oysters and corals which Burns found intercalated between the Vicksburg limestone and the Altamaha grits on the Ocmulgee river in Georgia, the Orthaulax bed and Tampa limestone of Tampa, Florida, and the chert of Hillsborough river. Heilprin's Cerithium rock also belongs here, and Bailey's "infusorial earth" of Tampa. The fauna which characterizes them is also found represented mechanically mixed with later forms in the marls of Shiloh, New Jersey.

This fauna is very closely allied to that of the Chipola beds and has not been completely worked out, but is intimately connected with the Miocene of the West Indies, Jamaica, Trinidad, Haiti, Curaçao, Panama and Costa Rica. Many of the species are the same as those of the Chipola fauna, but others are peculiar, sufficiently so to warrant the separation of the Chattahoochee from the Chipola as a distinct series. The forms which characterize the former alone, as far as our present knowledge goes, include Orthaulax pugnax, several species of Pyrazisinus, Cerithium hillsboroensis, Potamides transecta, Natica amphora, Cyrena vesica and Orbitolites floridanus. The last has been repeatedly mentioned as found in rocks of the Chipola series, and there is no particular reason why it should not occur there, since there is a recent species of Orbitolites not to be distinguished from Orbitolites floridanus, which has been dredged in large quantities on the Gulf coast by the United States Fish Commission. Nevertheless, the fact remains that so far I have been unable to detect any trace of this fossil in any of the typical Chipola beds, and believe that the report of its presence there is due to some misidentification. Certain corals and a peculiar oyster are very characteristic of the lower zones of the Chattahoochee everywhere, but have not yet been sufficiently studied to be precisely identified, and may also occur at higher levels. The same may be said of several echini. Since the Altamaha grits are of analogous and probably synchronous origin with the muchdebated Grand Gulf beds, it is probable, from Burns' observations, that the latter are in large part synchronous* with the Chattahoochee series; and the erosion by which the Grand Gulf sediments were formed may have started with the movement in elevation which finally raised these older Miocene beds in Costa Rica to a very considerable height above the sea.

\footnotetext{
* See Bal. 84, U. S. Geol. Survey, pp. 82, 83, 1892. Professor E. A. Smith, State Geologist of Alabama, from unpublished data had come to the conclusion as early as September, 1892, that the typical Grand Bluff beds should be correlated with the older Miocene of the Apalachicola section.
} 
The Chattahoochee limestone has been observed above the Vicksburg in southwestern Georgia (Bainbridge, Blue springs, Wileys landing), and in Florida, at the surface or overlaid only by the Lafayette (River Junction', conformably overlaid by the Chipola marl (McClellan's marl-bed, Chipola river), or by the Alum bluff beds (Old Chattahoochee landing, Aspalaga, Rock bluff).

Chipola Marl.-The Chipola marl which immediately overlies the Chattahoochee limestone is a very calcareous mixture of broken shells, fine clay, fossils, and fine sand. When in its normal state it is of a pale yellow, but at Alum bluff is oxidized to a dark red. It is replete with organic remains which are often in a fine state of preservation. More than 400 species have been collected by Burns and the writers, of which only a portion of the Gasteropods have been fully worked out. Orthaulax gabbi, Strombus aldrichi, Venus langdoni, many Cerites and Turritellas, Marginellas and Trochids are among the more conspicuous fossils. There is a remarkable absence of foraminifera and echinoids and the corals are few, mostly small, solitary species. The deposit is one which must have been formed under very favorable conditions of food-supply and in a depth of water greater than that which occurs within the limits of the tides. This explains its absence in the sections where the Chattahoochee is covered by beds which were obviously deposited in shallow water, as at Aspalaga, Rock bluff and old Chattahoochee landing. The observed thickness of the Chipola bed does not much exceed 15 feet, but in favorable localities it may hereafter be shown to have considerably exceeded this amount.

Alum Bluff Beds.-At Alum bluff the Chipola marl is conformably overlaid by the deposit named by Dall in 1891 the Alum bluff beds, which there attains a thickness of nearly 22 feet. The change at the point $A-B$, figure 2 , from the marl into the sands is not abrupt, but gradual, and takes place in a depth of about five feet, the fauna of the marl-bed being represented in the sands by quite a number of its species in this transition zone. Above the sands show no fossils or only phytogene remains. The composition of the Alum bluff beds is chiefly sand, with a little clay intermixed, and occasional apparently lenticular masses of clay almost pure. The sands are yellowish or pale; the clay pale gray, both oxidized in streaks, when they are of various shades of ferruginous yellow verging into orange. When the face of the bluff is cleared of weathered material the sands above the lower five or six feet are seen to be clearly and distinctly cross bedded. In the lower portion are numerous plant-remains, some of them, apparently palmettos, attaining a very large size and having the woody stems converted into streaks of lignite. The phenomena indicate clearly, as Foersto has 
already shown, that an elevation took place which raised the area of the marl to a point where the deep-water fauna forsook it, where vegetable matter was deposited, and where finally the water was so shoal as to admit of cross bedding from wave-action. These features are characteristic of the beds at the point $A-B$, figure 2 , where our chief section was made; but, following them northward in the face of the bluff for about a third of a mile, we perceive that a change takes place in the character of the sediments of which the bed is composed. They become more clayey and the sand is finer; the color changes from pale yellow to whitish, and finally to a pale gray or even a greenish tint. At point $C$, figure 2 , the transformation is complete, and the yellow color and crossbedding have disappeared entirely. In the bed at this point we did not observe any fossils, but its thickness is about the same as at $B$. Five miles further north, in the Rock bluff anticline, this bed reappears with a thickness of 63 feet, and here contains oyster-bed fossils, Ostrea, Pecten, Balanus, Anomia and Turritella, and it is again seen with the same fossils at Aspalaga. At Old Chattahoochee landing it is again unfossiliferous. It is also reported under the Chesapeake, at Jacksons bluff, on the Ochlockonee river, where it has the same fossils as at Rock bluff. This deposit clearly belongs to the Chipola series and represents that part of the latter which was deposited in shallow water, before the incursion of the Chesapeake fauna, during an epoch of elevation. The greatest thickness of the Alum bluff beds observed at Rock bluff is 63 feet. They were subsequently named the "Aspalaga marl " by Johnson,* and referred to his "Waldo formation," but they are physically continuous with the sands of the Alum bluff beds.

Farther west, at Oak Grove, on the Yellow river, Florida, what appears to be this same fauna occurs in a fine incoherent gray sand, with a number of species not found in the Chipola marl, including the Turritella (n. sp.), referred to as occurring at Rock bluff. It would seem, therefore, that this same zone is represented at that point, though the matrix is different. With a large number of these essentially old Miocene fossils collected at Oak Grove were sent by Professor E. A. Smith specimens of Pecten madisonius, Panopæa goldfussii and several other fossils, which latter occur in the Chesapeake at Alum bluff, but not in Maryland. These may represent a stratum above that in which the old Miocene fossils occur, or these species may be the precursors in that part of the Alum bluff beds of the advancing Chesapeake fauna. At present, owing to various circumstances, which need not be recapitulated hère, we incline

\footnotetext{
* Bull. Geol. Soe. Am., vol. 3, p. 130. On page 129 they are called in a foot-note the "Aspalaga clays," but clay is not predominant in them. The Waldo horizon is that of the newer Miocene (Chesapeake) at the typical locality, but its author in defining it combined with it beds at other localities belong. ing to the old Miocene.
} 
to the first supposition. There is a well marked Cardium (chipolanum n. sp.) in the Chipola marl which simulates in miniature the great Cardium magnum of the recent fauna. This is succeeded in the Alum bluff beds by another species extremely similar, but perfectly distinct. This occurs at Oak Grove. Cardium shipolanum is found in Johnson's Hattiesburg phase of the Grand Gulf beds at Roberts, Escambia county, Alabama. At the latter place Professor Smith informs us the sands containing the fossils lie directly upon genuine Grand Gulf beds (Johnson's Ellisville phase). If these observations be correct we probably have the Grand Gulf beds (strictly speaking) comprised between the Haw thorne beds below and the Alum bluff beds above, thus making them chronologically equivalent to the lower middle portion of the old Miocene rocks of west Florida. The Pascagoula clays of Johnson, formerly associated with the Grand Gulf beds, may be confidently referred to the newer portion of the newer or Chesapeake Miocene, and would therefore be separated by a considerable time-interval from the typical Grand Gulf rocks.

There is some reason to believe from fossils collected at De Funiak springs that the Alum bluff beds are represented there, but no question of this sort can be answered permanently without a careful study of the stratigraphy in combination with an intelligent knowledge of the fauna. Attempts to theorize on the geology of the southern Tertiary from a few imperfectly identified species of fossils and without exact determinations of the stratigraphy are worse than useless, as they multiply error and confusion.

The Chipola series may be summarized as containing the Chipola marl, the Roberts, Escambia county, Alabama, sands and the Alum bluff beds, which, with the Chattahoochee formation, comprise the subtropical or old Miocene division of the Miocene of the southern and eastern United States.

Chesapeake or cold Water Miocene.-Just above the Alum bluff beds in the section $A-B$, at Alum bluff, lies the gray Chesapeake or newer Miocene marl, consisting of an arenaceous greenish gray clay, crammed with fossils. Here the bed is deposited conformably upon the Alum bluff sands, but sharply contrasted with them, both in color and coherende. It reaches here a thickness of 35 feet, which diminishes gradually northward to not more than 5 or 6 feet at point $C$, figure 2. The upper few feet form a zone which is more or less oxidized and has the fossils dissolved out, owing to seepage of acidified water from the bed above. The fauna of the Chesapeake at Alum bluff includes about 200 species, among which Venus rileyi, Conus adversarius, Turritella variabilis, Fusus equalis, Dentalium attenuntum, Ecphora quadricostata and Crucibulum constrictum 
are prominent species and Mactra congesta the most abundant fossil. The color of the bed and of the fossils in the bed is exactly like that of the Maryland beds of the same age, their cold gray and chalky white color contrasting vividly with the yellow and ferruginous tints of the old Miocene marl and its fossils.

This bed has been recognized lying upon the Alum bluff beds at Jacksons bluff, Ochlockonee river (Jussen), and below the Lafayette or red beds and the aluminous clay at Abes spring and Darlings slide. It also occurs near Tallahassee and is reported on Johnson's authority from De Funiak springs. It is probable that this fauna, which has been shown by. Dall and Harris* to have penetrated into the gulf of Mexico by the strait named by them the Suwannee strait, $\dagger$ never extended westward of the Mississippi embayment, the synchronous fauna on the Texan side of that gult partaking much more strongly of subtropical and $\mathrm{Pa}$ cific coast elements. It would not be surprising if, as suggested by Foerste, a mingling of the earlier Chesapeake and latest Chipola species were found to occur at some point on the Gulf coast. But it must be distinctly understood that no reliable evidence of such a mingling, as distinguished from an accidental mechanical mixture of fossils of different ages, has yet been shown to exist anywhere. The Oak Grove fossils authorize the inquiry, but cannot as yet offer any proof of such a mixture. The locality would be worth examination by any trained observer who would take the time and trouble to definitely ascertain the exact facts, which are not yet at our disposal.

The Chesapeake marl reaches 7 feet above the water at Abes springs. At Darlings slide there is uncertainty as to its exact thickness, but at neither place is its base discernible or any subjacent rock visible. At Jacksons bluff it is 8 feet thick.

The Aluminous Clay.-Above the Chesapeake marl at Alum bluff is a bed of grayish clay, apparently more pervious than the marl, as water issues from it all along its face, and, trickling down, leaves an efflorescence on the surface, from which the bluff derives its name. This clay is 24 feet thick, and was termed "lignitic" by Langdon and Johnson, but contains extremely little vegetable matter, as Foerste pointed out. $\ddagger$ We found evidences of fossils, too much dissolved to identify, in this clay, and Mr Foerste states that he found Chesapeake species in it, but does not mention which species. It is highly probable that the clay is of Chesapeake age, and, as it exactly resembles the so-called Pascagoula clay of Vernal, Mississippi, which contains at least one Chesapeake spe-

* Bull. 84, U. S. Geol. Survey, 1891.

† Op. cit., p. 111 ; the name of Okeefinokee has since been applied to it by Foerste (Am. Jour. Sci., vol. 46 , October, 1893, p. 245), who donbtless overlooked the fact that it had previously been named. $\ddagger$ Op. cit., p. 250 . 
cies (Mactra lateralis, Say) belonging to the newer Chesapeake, it is probable that the Pascagoula beds should also be referred to this horizon. The aluminous clay was also recognized in a bed, 19 feet thick, above the Chesapeake marl at Abes spring, and part of the 27 feet assigned to the Chesapeake at Darlings slide is probably of this horizon, though, owing to the verticality of the bluff, its face could not be closely examined at this height, and the line of distinction between the two, if it exists, had been so obscured by the rush of huge logs over the surface that it could not be recognized from the foot of the bluff.

This completes the summary of the Miocene section of the Apalachicola region. It has involved some repetition of previously mentioned details, but this was thought best to avoid obscurity.

\section{PLIOCENE.}

There was found near the top of every section studied on the Apalachicola river a bed which in general was composed of a mixture of yellow and red colored sands and clays, the predominating tint and composition of the material varying with the locality. The thickness of this bed in each case has been shown in the descriptions of the sections. It has already been noted that in the vicinity of Bainbridge this material is of considerable thickness and homogeneous in texture, highly argillaceous and of a uniform red color throughout; also that in some places it has the appearance of a decomposition product in situ, while in others rearrangement of the material is apparent, yet each so simulating the other as to make identification at times difficult. This condition of affairs continues with considerable uniformity northward to Macon, but it is safe to say that there is greater heterogeneity in this material in the limited area studied than there is in its greater northward extension. At Old Chattahoochee landing it preserves its Bainbridge characteristics and rests upon an erosion surface. At Aspalaga and Rock bluff modification is more noticeable, and when Alum bluff is reached on the seaward route this formation is represanted by a bed nearly 70 feet thick, highly arenaceous, fine in texture; in color, orange and white, so alternating as to present a mottled appearance, and, while even this portion of the bluff has a stratified aspect, there is some evidence of plunge and flow structure. It also rests conformably upon the bed of aluminous clay which immediately overlies the Chesapeake. A little farther south and 12 or 15 miles to the westward, at Abes spring and Darlings slide, the sand of which it is composed is coarser, the mottlings have a marked red and yellow color, plunge and flow structure is more pronounced and, as at Alum bluff, it rests apparently conformably upon the aluminous clay overlying the Chesapeake. From our observation we conclude that, though often different in composition, structure and color, it is never- 
theless a continuation of the more homogeneous formation to the northward, the modifications having been brought about by the agencies to which it was subjected in its seaward extension. There would seem to be no question as to the propriety of referring it, as we have done, to the Lafayette of Hilgard and McGee, and from the studies of the fossilbearing beds alone it can be stated with a reasonable degree of certainty that it is not earlier than the Pliocene.

\section{PLEISTOCENE.}

In almost every instance there was observed resting upon the preceding formation a veneer 3 or 4 feet thick of incoherent, superficial sand, which in nearly all cases has the appearance of such fine sandy material as is deposited in the sea by the sluggish southern rivers. At Alum bluff it presents more the aspect of washed beach-sand, but in all exposures examined bowlders and large pebbles were conspicuously absent. The opportunities for studying this surface bed were too limited to warrant the presentation of any positive opinions as to its relation to similar materials of the region to the eastward or westward. It is probably, however, a remnant of the Pleistocene Columbia, which, along the seaward portion of North Carolina, South Carolina and Georgia, has been found by McGee and others to cover the Iafayette as a mantle of varying thickness.

\section{Correlation.}

The following preliminary correlation of the Miocene beds differs slightly from that of Bulletin 84, United States Geological Survey, and also from that of Mr Foerste, owing to the receipt of additional material and our personal later observations on the ground. More knowledge is required both of the fossils and the stratigraphy before a finality can be reached in the correlations, but as far as the Apalachicola section itself is concerned, we believe it now rests upon a solid foundation.

Apalachicola Section.

Aluminous clay ..................Pascagoula clays (?)

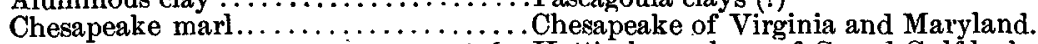

Alum bluff beds. ............ 8 \& $\{$ Hattiesburg phase of Grand Gulf beds.

Alum

Chipola marl............... $\{$ Roberts, Alabama, sand.

政\{ $\left\{\begin{array}{l}\text { Bainbridge residual beds, Georgia. } \\ \text { Bainbridge, Georgia, residual beds. }\end{array}\right.$

Upper Chattahoochee beds...... $\{$ Altamaha grits.

Lower Chattahoochee beds.......

Vicksburg Eocene............... Vicksburg Eocene.

The total thickness of this Miocene will hardly exceed 200 feet along the Apalachicola river. 